University of Nebraska - Lincoln

DigitalCommons@University of Nebraska - Lincoln

Faculty Publications from the Harold W. Manter Laboratory of Parasitology

4-1965

\title{
Studies on the Helminth Fauna of Alaska. XLII. Aploparaksis turdi sp. n., a Hymenolepidid Cestode from Thrushes
}

Francis S.L. Williamson

United States Department of Health, Education and Welfare

Robert L. Rausch

University of Washington, rausch@uw.edu

Follow this and additional works at: https://digitalcommons.unl.edu/parasitologyfacpubs

Part of the Parasitology Commons

Williamson, Francis S.L. and Rausch, Robert L., "Studies on the Helminth Fauna of Alaska. XLII.

Aploparaksis turdi sp. n., a Hymenolepidid Cestode from Thrushes" (1965). Faculty Publications from the Harold W. Manter Laboratory of Parasitology. 382.

https://digitalcommons.unl.edu/parasitologyfacpubs/382

This Article is brought to you for free and open access by the Parasitology, Harold W. Manter Laboratory of at DigitalCommons@University of Nebraska - Lincoln. It has been accepted for inclusion in Faculty Publications from the Harold W. Manter Laboratory of Parasitology by an authorized administrator of DigitalCommons@University of Nebraska - Lincoln. 


\title{
Studies on the Helminth Fauna of Alaska. XLII. Aploparaksis turdi sp. n., a Hymenolepidid Cestode from Thrushes
}

\author{
Francis S. L. Williamson and Robert L. Rausch \\ Arctic Health Research Center, Public Health Service, \\ U. S. Department of Health, Education, and Welfare, Anchorage, Alaska
}

ABSTRACT: Aploparaksis turdi sp. n. (Cestoda : Hymenolepididae) is described from the robin, Turdus migratorius L., and recorded also from the varied thrush, Ixoreus naevius (Gmelin), from Iliamna Lake, upper Alaska Peninsula. This cestode is distinguished from the three previously known species of Aploparaksis s. l. occurring in passeriform birds by the size and number of rostellar hooks and by the arrangement and proportions of the genital organs. It is concluded that the validity of the genus Monorcholepis Oshmarin, 1961, to which certain of these species have been assigned, is questionable, and the latter genus is considered to be a synonym of Aploparaksis Clerc, 1903.

In May and June 1958 and 1959, one of us (F. S. L. W.) collected helminths from passerine birds in the vicinity of Iliamna Lake, on the upper Alaska Peninsula. Subsequent examination of the stained preparations revealed cestodes of a species referable to the genus Aploparaksis Clerc, 1903, described herein as new.

The new cestode was found in 3 of 20 robins, Turdus $m$. migratorius L. One bird harbored two large cestodes with early gravid segments, and the other two birds had single, immature worms. This cestode was also found in three varied thrushes, Ixoreus naevius meruloides (Swainson), collected in the same area where the infected robins were obtained. These tapeworms were all immature.

The cestodes were stained in Semichon's acetic carmine, cleared in terpineol, and mounted entire. Rostellar hooks from some of the scolices were mounted separately in order to facilitate measurement.

\section{Aploparaksis turdi sp. $\mathbf{n}$.}

(Figs. 1-3)

(All measurements in microns unless otherwise indicated)

\section{Diagnosis}

Length of strobilae with early gravid segments 76 and $95 \mathrm{~mm}$; maximum width 0.800 to $1.0 \mathrm{~mm}$, attained near posterior end of strobila. Terminal segments narrower. Anterior portion of strobila much attenuated; unsegmented neck 0.7 to $1.0 \mathrm{~mm}$

Received for publication 30 November 1964. long, with external segmentation becoming distinct about $3.0 \mathrm{~mm}$ posterior to scolex. Strobilar margins serrate. All segments wider than long; length/ width ratio $1: 6$ to $1: 10$ in mature segments, and about $1: 7$ in widest pregravid segments. Scolex relatively large, 340 to 400 in diameter; suckers well developed, 112 to 149 (avg 125) in diameter. Rostellum provided with single row of 27 to 31 (avg 28) hooks measuring 33 to 38 (avg 36) in length. Handle of hook conspicuous, somewhat variable in form, and exceeding guard in length; blade and guard nearly equal in length, with guard only slightly shorter. Genital primordia visible immediately posterior to neck, about $1.0 \mathrm{~mm}$ from scolex. Genital pores unilateral and dextral, situated near middle of segmental margin. Cirrus sac long and relatively slender, 332 to 439 (avg 384 ) long and 43 to 58 wide near proximal end, extending mediad to beyond midline of segment. Cirrus spinose and of uniform diameter. Internal seminal vesicle large, situated in proximal third of cirrus sac. External seminal vesicle well developed, measuring 111 to 124 (avg 118 ) by 41 to 53 (avg 49), more or less ovoid to piriform, situated near midline in anterior half of segment; it curves toward distal end of cirrus sac along anterodorsal surface of latter, its proximal end overlapped dorsally by testis. Testis more or less ellipsoidal, large, measuring 126 to 202 (avg 165) by 83 to 116 (avg 95), with long axis oriented transversely; it occupies almost full length of segment from just aporal of midline to, and sometimes slightly overlapping, aporal longitudinal excretory canals. Testis overlaps dorsally portion of external seminal vesicle and proximal end of cirrus sac. Vagina, situated ventral to cirrus sac, comprised of thin-walled tube measuring 12 to 15 in diameter; it extends mediad from genital pore along ventral surface of cirrus sac, becoming increasingly convoluted and forming one or more loops just mediad of longitudinal excretory canals after which it joins large seminal 

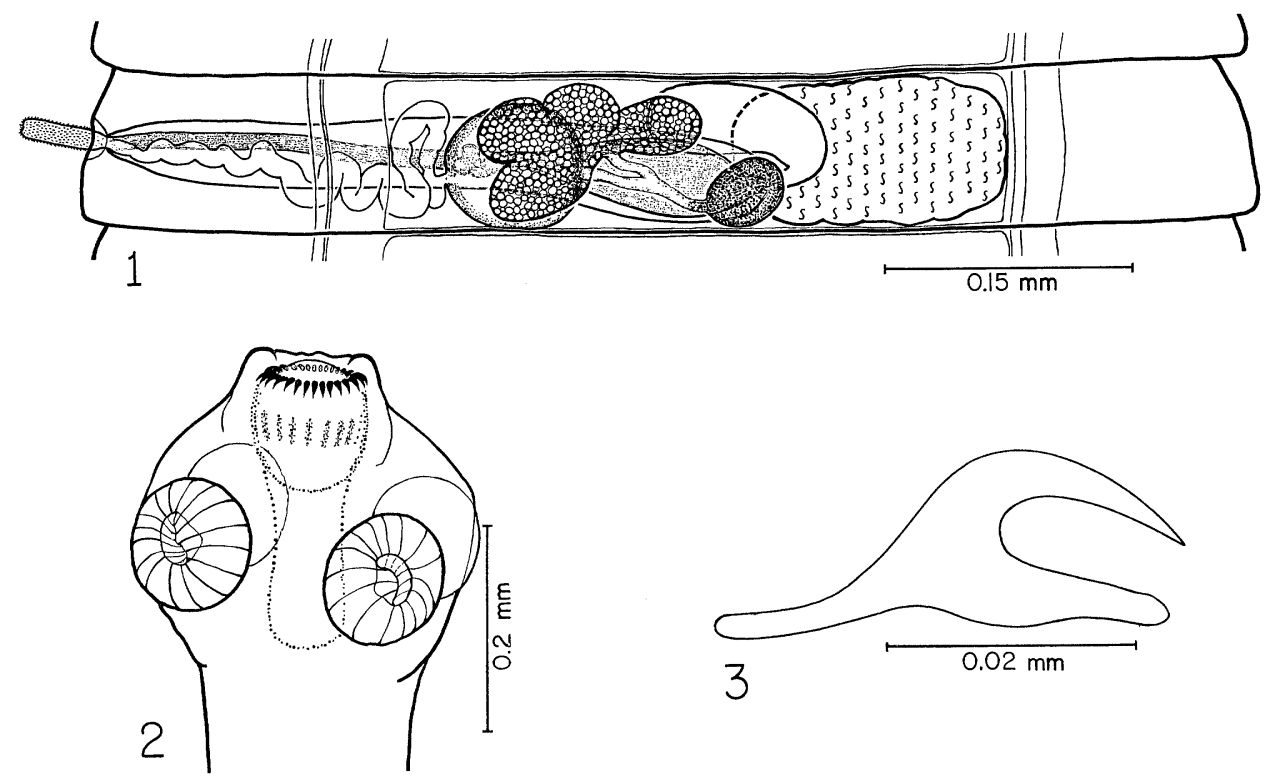

FigUREs 1-3. Aploparaksis turdi sp. n. from the robin and varied thrush in Alaska. 1. Mature segment, ventral view. 2. Scolex. 3. Rostellar hook.

receptacle. Latter is thin-walled, subspherical structure, measuring 83 to 100 (avg 94 ) by 50 to 96 (avg 76), and extending from posterior margin of segment anteriad at least to anterior margin of cirrus sac; it is situated between cirrus sac and ovary, overlapping dorsally poral lobes of latter organ. Lobed ovary large, extending through greater part of segmental length, and situated near middle of segment with greater part on poral side of midline. Comprised of three to five lobes, ovary measures 132 to 185 in greatest (transverse) length. Subspherical vitelline gland, measuring 52 to 73 in greatest diameter, situated near posterior margin of segment ventral to proximal end of cirrus sac and posterior to aporal portion of ovary. Uterus appears in pregravid segments as transverse, ventral structure extending to or slightly beyond poral and aporal longitudinal excretory canals. Uterus increases in anteroposterior length, gradually becoming sacculate and finally filling entire segment to level of excretory canals on both sides. Mature eggs not observed.

Host: Robin, Turdus migratorius L. Also recorded from the varied thrush, Ixoreus naevius (Gmelin).

Habitat: Small intestine of host.

Type locality: Iliamna Lake, upper Alaska Peninsula.

Type: A slide containing an entire cestode has been deposited in the Helminthological Collection of the U. S. National Museum, No. 60100.

\section{DISCUSSION}

About 55 species or subspecies of cestodes have been assigned to the genus Aploparaksis
Clerc, 1903. However, in his monograph of the Hymenolepididae, Spasskii (1963) retained only 35 species or subspecies (i.e., cestodes having ten rostellar hooks and a single testis) in the genus Aploparaksis s. str. Of these 35 forms, 29 occur in charadriiform birds, 3 in anseriforms, and 1 each in galliforms, gruiforms, and passeriforms. The remaining were either placed in synonymy or transferred to other genera.

Cestodes of the genus Aploparaksis s. 1. exhibit a high degree of host specificity, and only six species or subspecies from passeriform birds are considered in connection with the species described here. Of these, only A. skriabini Spasskii, 1945, from a jay, Garrulus glandularius (L.) (Smolensk Oblast', USSR), was retained by Spasskii (1963) in the genus Aploparaksis.

Among the remaining species, the status of A. linstowi (Kintner, 1938)must be considered. A cestode designated Aploparaksis fringillarum (Rudolphi, 1810), reported from various species of finches and tits, was studied by von Linstow (1904). This cestode, having ten hooks, was stated by von Linstow to possess a single, multilobed testis. Fuhrmann (1908), remarking that von Linstow's assignment of this cestode to Aploparaksis was in error, trans- 
ferred it to the genus Hymenolepis Weinland, 1858 , and noted that $H$. fringillarum ( $\mathrm{Ru}-$ dolphi, 1810) might be a synonym of Taenia passeris Gmelin, 1790. Kintner (1938) reported Hymenolepis passeris (Gmelin, 1790) from a sparrow, Passer domesticus L., in Indiana, considering $T$. fringillarum Rudolphi, 1810 , a synonym of $H$. passeris. In comparing his material with the descriptions of $T$. fringillarum by Krabbe (1869) and von Linstow (1904), he concluded that his cestode agreed closely with the inadequate description published by Krabbe. Since von Linstow had stated that Aploparaksis fringillarum $(=T$. fringillarum) had but a single, multilobed testis, Kintner believed that Krabbe and von Linstow had studied two different species, and accordingly proposed the name Haploparaxis linstowi (= A. linstowi) Kintner, 1938, for the cestode described by von Linstow, thus making A. linstowi a synonym of Hymenolepis passeris. Spasskii and Spasskaia (1954) established the genus Passerilepis, designating $P$. passeris (Gmelin, 1790) the type species, and listing T. fringillarum Rudolphi, 1810, as a synonym. Haploparaxis (= Aploparaksis) linstowi was retained as a valid species by Yamaguti (1959), but it was properly listed as a synonym of Passerilepis passeris by Spasskii (1963). Consequently, A. linstowi (= P. passeris) is not considered further in the present paper.

Three species or subspecies of cestodes formerly assigned to the genus Aploparaksis, A. dujardini (Krabbe, 1869), A. dujardini neoarcticus Webster, 1955, and A. passerellae Webster, 1952, all from passeriform birds, were assigned by Spasskii (1963) to the genus Monorcholepis Oshmarin, 1961. Although the original definition of this genus has been unobtainable, it is evident from the key published by Spasskii $(1963, \text { p. } 84)^{1}$ that it is based upon the position of the ovary (poral to vitelline gland and testis), the number and form of the

${ }^{1}$ The diagnosis of the genus Monorcholepis is included in a more recent publication by Oshmarin (1963, p. 141), obtained since the present manuscript was sent to press (Paraziticheskie chervi mlekopitaiushchikh i ptits Primorskogo kraia, Akad. Nauk SSSR, Sibirsk. otdel., Moscow, 1963, 322 p.). The interpretation from Spasskii's key is essentially correct, but the species of this genus are stated only to be "parasites of the intestine of birds." rostellar hooks (greater than ten; handle reduced), and host occurrence (primarily in turdids). A. turdi sp. n. conforms to these criteria, except that the hook possesses a welldeveloped handle. At the present time, it seems doubtful that Monorcholepis differs sufficiently from Aploparaksis to justify its status as a separate genus.

One additional species assigned previously to the genus Aploparaksis, A. elisae Skriabin, 1914, from a duck in Eurasia, was identified by Cooper (1921) from fragmentary material obtained from a fox sparrow, Passerella iliaca (Merriam), in Alaska. Not only is the determination questionable, but $A$. elisae has been transferred to the genus Diorchis Clerc, 1903, by Spasskii and Freze (1961; cited in Spasskii, 1963). Consequently, this species is not considered further here.

A. turdi may be compared with four species or subspecies known to occur in passeriform birds:

A. dujardini has a larger number of rostellar hooks ( 42 to 48 ) of smaller size (19 to $21 \mu$ ), and of different shape (lacking handle). It also has a smaller cirrus sac and differs in other details of the genital organs. A. dujardini neoarcticus differs from $A$. $d$. dujardini in minor details that probably only represent normal morphological variation of the latter species.

A. skrjabini has only ten hooks of different shape and size, and also has a different arrangement of the genital organs.

A. passerellae has fewer hooks (25) of much smaller size $(13 \mu)$ and of dissimilar shape (handle much reduced). The details of the genital organs are unlike those of A. turdi.

Until the status of the genus Monorcholepis has been clarified, it seems advisable to retain the aforementioned species from passeriform birds in the genus Aploparaksis.

\section{ACKNOWLEDGMENTS}

We are indebted to the following persons for assistance in connection with this work: Mrs. V. R. Rausch, Arctic Health Research Center, prepared the figures; Mr. Leonard J. Peyton, University of Alaska, participated in the fieldwork; Mr. Kenneth L. Austerman, Arctic Health Research Center, provided photographic assistance. 


\section{LITERATURE CITED}

Cooper, A. R. 1921. Trematodes and cestodes of the Canadian Arctic Expedition, 1913-18. Report of the Canadian Arctic Exped. 191318. Vol. 9, Pt. G-H. 27 p.

Fuhrmann, O. 1908. Die Cestoden der Vögel. Zool. Jahrb. Suppl. 10 (1): 1-232.

Kintner, K. E. 1938. Notes on the cestode parasites of English sparrows in Indiana. Parasitology 30: $347-357$.

Krabbe, H. 1869. Bidrag til Kundskab om Fuglenes Baendelorme. K. Danske Vidensk. Selsk. Skr., Naturv. og Math. Afd. 8: 249-363.
SpasskiI, A. A. 1963. Gimenolepididy-lentochnye gel'minty dikikh i domashnikh ptits. Pt. 1. Osnovy Tsestodologii. Vol. 2. 417 p. Akad. Nauk SSSR, Moscow.

-, and L. P. Spasskaia. 1954. Postroenie sistemy gimenolepidid, parazitiruiushchikh u ptits. Trudy Gel'mint. Lab. 7: 55-119.

von Linstow, O. 1904. Beobachtungen an Nematoden und Cestoden. Arch. Naturg. 70: 297-309.

Yamaguti, S. 1959. Systema helminthum. Vol. 2. The cestodes of vertebrates. Interscience Publ., Inc., New York. 860 p.

\section{Hughes Virus, a New Arboviral Agent from Marine Bird Ticks}

When Hughes et al. (1964, Am. J. Trop. Med. Hyg. 13: 118-122) reported and characterized a distinct viral isolate from soft ticks taken in tern nests on Bush Key, Dry Tortugas Island, proposal of a common name for the virus was postponed for the intended second report on tests of tick transmission. Such tests have proved unexpectedly difficult because of reluctance of the Ornithodoros capensis complex, from which the virus was isolated, to accept feedings in the laboratory.

Meantime, others who have isolated the same tick-borne virus and are subjecting it to laboratory study are in need of a name for concise reference. The common name "Hughes virus" is herewith proposed and dedicated to the investigator who first isolated the virus from a species of marine bird tick to be described shortly (Kohls et al., Ann. Ent. Soc. Amer., in press).

Serologically, this agent shows no relationship to many other arboviruses including those in Groups A and B, in studies at the Rocky Mountain Laboratory and the Virus Laboratories, Rockefeller Foundation, New York. Unpublished information at the latter institution reveals serological evidence of antibodies against the Hughes virus in sea birds "far afield" in the Antarctic. A similar but apparently not immunologically identical isolate was obtained by us from the same tick species collected from sea bird nests on Raza Island, Gulf of Baja California.

The $O$. capensis tick complex is already known from sea bird rookeries in various oceans and records are expanding which is not surprising in view of the wide-ranging habits of marine bird hosts. The virus may therefore be expected in other areas and two recent viral isolates by us from true $O$. capensis from sooty tern nests on isolated Johnson Island in the Central Pacific, may also prove to be related here. A common, restrictive place name does not appear appropriate for the tick-borne virus originally characterized by us from Dry Tortugas marine bird ticks.

Transstadial survival of Hughes virus in $O$. capensis fed through membranes on virus pools has been observed by us but a susceptible host acceptable to the ticks has not yet been found for demonstration of transmission by bite. In easily propagated $O$. moubata, in which certain viral and rickettsial agents are known to persist, the Hughes virus is denatured in $48 \mathrm{hr}$.

Cornelius B. Philip, Hamilton, Montana 